\title{
Heat Treatment of Bovine Colostrum. I: Effects of Temperature on Viscosity and Immunoglobulin G Level
}

\author{
S. McMartin, ${ }^{\star}$ S. Godden, ${ }^{\star 1}$ L. Metzger,† J. Feirtag,† R. Bey,‡ J. Stabel,§ S. Goyal,‡ J. Fetrow, ${ }^{\star}$ \\ S. Wells, ${ }^{*}$ and H. Chester-Jones\# \\ *Department of Veterinary Population Medicine, \\ †Department of Food Science and Nutrition, and \\ $\ddagger$ Department of Veterinary and Biomedical Sciences, University of Minnesota, St. Paul 55108 \\ §USDA, ARS, National Animal Disease Center, Ames, IA 50010 \\ \#Department of Animal Science, University of Minnesota, St. Paul 55108
}

\begin{abstract}
The objective of this study was to identify the critical temperature, at or below which heat-treatment of bovine colostrum would produce no significant changes in viscosity, IgG concentration, or Ig activity. Results of preliminary work, using a Rapid Visco Analyzer (RVA) to heat 50-mL aliquots from 6 unique batches of bovine colostrum at $59,60,61,62$, and $63^{\circ} \mathrm{C}$, suggested that colostrum could be heated to $60^{\circ} \mathrm{C}$ for up to 120 min without changing viscosity or IgG concentration. This finding was confirmed by heating $50-\mathrm{mL}$ aliquots from 30 unique batches of colostrum in an RVA for $120 \mathrm{~min}$ at 60 and $63^{\circ} \mathrm{C}$. Heating colostrum to $63^{\circ} \mathrm{C}$ resulted in an estimated $34 \%$ decrease in IgG concentration and $33 \%$ increase in viscosity. However, there was no difference in IgG concentration between preheat-treated $(73.4 \pm 26.5 \mathrm{mg} / \mathrm{mL})$ and post-heattreated $(74.5 \pm 24.3 \mathrm{mg} / \mathrm{mL})$ samples after heating colostrum to $60^{\circ} \mathrm{C}$ in an RVA for $120 \mathrm{~min}$. Similarly, viscosity was unaffected after heating colostrum to $60^{\circ} \mathrm{C}$ in an RVA for $120 \mathrm{~min}$. High quality colostrum $(\geq 73.0 \mathrm{mg} / \mathrm{mL})$ suffered greater losses of IgG and greater viscosity changes when heated to $63^{\circ} \mathrm{C}$ than did moderate quality colostrum $(<73.0 \mathrm{mg} / \mathrm{mL})$. However, the effects of colostrum quality were minor if high quality colostrum was only heated to $60^{\circ} \mathrm{C}$. The results of a bovine viral diarrhea serum neutralization assay suggested that antibody activity was unchanged after heating colostrum to either 60 or $63^{\circ} \mathrm{C}$. However, these results were interpreted as being inconclusive due to a high proportion of missing results because of the congealing of many samples after heat treatment. The results of this study indicate that $50-\mathrm{mL}$ volumes of bovine colostrum can be heat treated at $60^{\circ} \mathrm{C}$ for up
\end{abstract}

Received November 14, 2005.

Accepted January 3, 2006.

${ }^{1}$ Corresponding author: godde002@umn.edu to 120 min in an RVA without affecting IgG concentration or viscosity.

Key words: colostrum, pasteurization, viscosity, immunoglobulin

\section{INTRODUCTION}

Recent National Animal Health Monitoring System dairy studies have reported that an unacceptably high mortality rate (8.4 to $10.7 \%$ ) exists among preweaned dairy heifers on US dairy farms (NAHMS, 1993, 1996, 2002). Wells et al. (1996) estimated that $31 \%$ of the mortality events occurring within the first $3 \mathrm{wk}$ of life could be attributed to failure of passive transfer of immunity. Although the cornerstones of a successful colostrum management program have traditionally considered colostrum quality, the volume fed, and age of calf at first feeding (Davis and Drackley, 1998), experts have recently suggested that bacterial contamination of colostrum may also be important (McGuirk and Collins, 2004). Some bacterial pathogens that may be transmitted in colostrum and milk (from direct shedding from the mammary gland, postharvest contamination, or bacterial proliferation in improperly stored colostrum) include Mycoplasma spp. (Walz et al., 1997), Mycobacterium avium ssp. paratuberculosis (Streeter et al., 1995), Escherichia coli (Clark et al., 1989; Steele et al., 1997), Salmonella spp. (McEwen et al., 1988; Giles et al., 1989; Steele et al., 1997), Listeria monocytogenes (Farber et al., 1988; Steele et al., 1997), and Campylobacter spp. (Lovett et al., 1983; Steele et al., 1997). In one observational study of commercial dairies, Poulsen et al. (2002) reported that $82 \%$ of colostrum samples collected exceeded the industry goal of $100,000 \mathrm{cfu} / \mathrm{mL}$ total plate count, suggesting that feeding contaminated colostrum is a common occurrence on commercial dairy farms (McGuirk and Collins, 2004).

The first control point in feeding clean colostrum must be to prevent contamination during the harvest, storage, and feeding processes (Stewart et al., 2005). 
Management strategies to prevent bacterial proliferation in stored colostrum may include freezing, refrigeration, and the use of preservative agents such as potassium sorbate in refrigerated fresh colostrum (Stewart et al., 2005). One additional method of reducing or eliminating bacterial pathogens is to heat-treat fresh bovine colostrum. The adoption of commercial on-farm pasteurization systems for the purpose of pasteurizing nonsaleable milk has been reported to result in significant health and economic benefits for calves and producers, respectively (Jamaluddin et al., 1996; Godden et al., 2005). These on-farm pasteurization systems typically utilize the same pasteurization times and temperatures recognized by the Grade A Pasteurized Milk Ordinance (US Department of Health and Human Services, 1999) to eliminate important pathogens. However, early studies that pasteurized colostrum, using the same times and temperatures recommended for milk, demonstrated that heating resulted in denaturation of from 12 to $30 \%$ of colostral IgG and sometimes caused significant increases in viscosity (Meylan et al., 1995; Godden et al., 2003; Green et al., 2003).

The objective of this study was to identify the critical temperature at or below which heat treatment of bovine colostrum would produce no significant change in colostrum viscosity, IgG concentration, or Ig activity.

\section{MATERIALS AND METHODS}

\section{Laboratory Methods}

First milking colostrum for this study was previously collected from Holstein cows on one commercial dairy farm, and frozen at $-20^{\circ} \mathrm{C}$ for between 2 and 16 wk. Preliminary work involved using a Rapid Visco Analyzer (RVA) to heat 50-mL aliquots from 6 unique batches of bovine colostrum to $59,60,61,62$, and $63^{\circ} \mathrm{C}$. The RVA is a computer-integrated instrument developed by Newport Scientific (Warriewood, Australia) that is capable of rapidly measuring the apparent viscosity (in $\mathrm{cP}$ ) of products over a range of temperatures and mixing conditions. For each run, the RVA held the sample at $38^{\circ} \mathrm{C}$ for $10 \mathrm{~min}$, heated it to the target pasteurization temperature over a 30 -min period, held it at the target temperature for $120 \mathrm{~min}$, and then cooled it to $38.5^{\circ} \mathrm{C}$ (approximate feeding temperature) over a 30 -min period. Temperature and viscosity were recorded at 8-s intervals during this procedure. Preand post-heat-treated colostrum samples were frozen at $-20^{\circ} \mathrm{C}$.

Frozen colostrum samples were submitted to the Veterinary Diagnostic Laboratory (University of Minnesota) for analysis of IgG concentration and activity. Analysis of colostrum samples for total IgG concentra- tion $(\mathrm{mg} / \mathrm{mL})$ was completed using a turbidometric immunoassay using an Olympus AU400e immunoanalyzer (Olympus America Inc., Melville, NY) and reagents from Midland Bioproducts Corp. (Boone, IA). The turbidometric immunoassay is a highly sensitive automated lateral-flow immunoassay that directly measures turbidity of the antigen-antibody complex, producing accurate IgG measures compared with the more time-consuming and labor intensive radial immunodiffusion (RID) method (Etzel et al., 1997; McVicker et al., 2002).

After reviewing the results of this preliminary work, it was determined that the approximate lower critical temperature, at or below which antibodies and viscosity would not be affected, was $60^{\circ} \mathrm{C}$. To verify that this was true over a larger number of samples, the abovedescribed RVA heating and testing process was repeated for 50-mL aliquots from 30 unique batches of bovine colostrum, in which the samples were only heated to 60 and $63^{\circ} \mathrm{C}$. In addition to measuring viscosity and IgG concentration for these 30 batches, a serum neutralization ( $\mathbf{S N}$ ) assay was used to evaluate antibody activity in colostrum samples. Frozen samples of colostrum were thawed at room temperature and then centrifuged at $28,800 \times g$ for $2 \mathrm{~h}$. Clear whey was used as the starting material for the SN assay. Antibodies against bovine viral diarrhea virus type 1 (BVDV-1) were determined using a microtitration SN test. Serial 2 -fold dilutions of whey were made in Eagle's mimimal essential medium with Earle's salts, $150 \mathrm{IU} / \mathrm{mL}$ of penicillin, $150 \mu \mathrm{g} / \mathrm{mL}$ of streptomycin, $50 \mu \mathrm{g} / \mathrm{mL}$ of neomycin, and $1 \mu \mathrm{g} / \mathrm{mL}$ of fungizone. Each dilution $(25 \mu \mathrm{L})$ was placed in wells of a 96 -well, flat-bottomed microtiter plate followed by the addition of an equal volume of virus suspension containing approximately 300 TCID $_{50}$ (tissue culture infective dose $50 \%$ ) of BVD-1 (Singer strain). The whey-virus mixture was incubated at $37^{\circ} \mathrm{C}$ for $60 \mathrm{~min}$. A suspension of bovine turbinate cells $\left(5 \times 10^{5}\right.$ cell $\left./ \mathrm{mL}\right)$ was then added to all wells at $50 \mu \mathrm{L}$ per well. A drop of mineral oil was placed in all wells to minimize liquid evaporation. The plates were incubated at $37^{\circ} \mathrm{C}$ in a $5 \% \mathrm{CO}_{2}$ atmosphere for $7 \mathrm{~d}$. Each set of plates had cell controls and a virus backtitration in addition to individual whey controls. Antibody titers were expressed as the reciprocal of the highest dilution that prevented the development of viral cytopathic effects.

\section{Statistical Methods}

For the preliminary work using 6 unique batches of colostrum heated to 5 different temperatures $(59,60$, 61,62 , and $63^{\circ} \mathrm{C}$ ), descriptive statistics were used to describe measures for viscosity $\left[\log _{10}(\mathrm{cP})\right]$ and IgG con- 


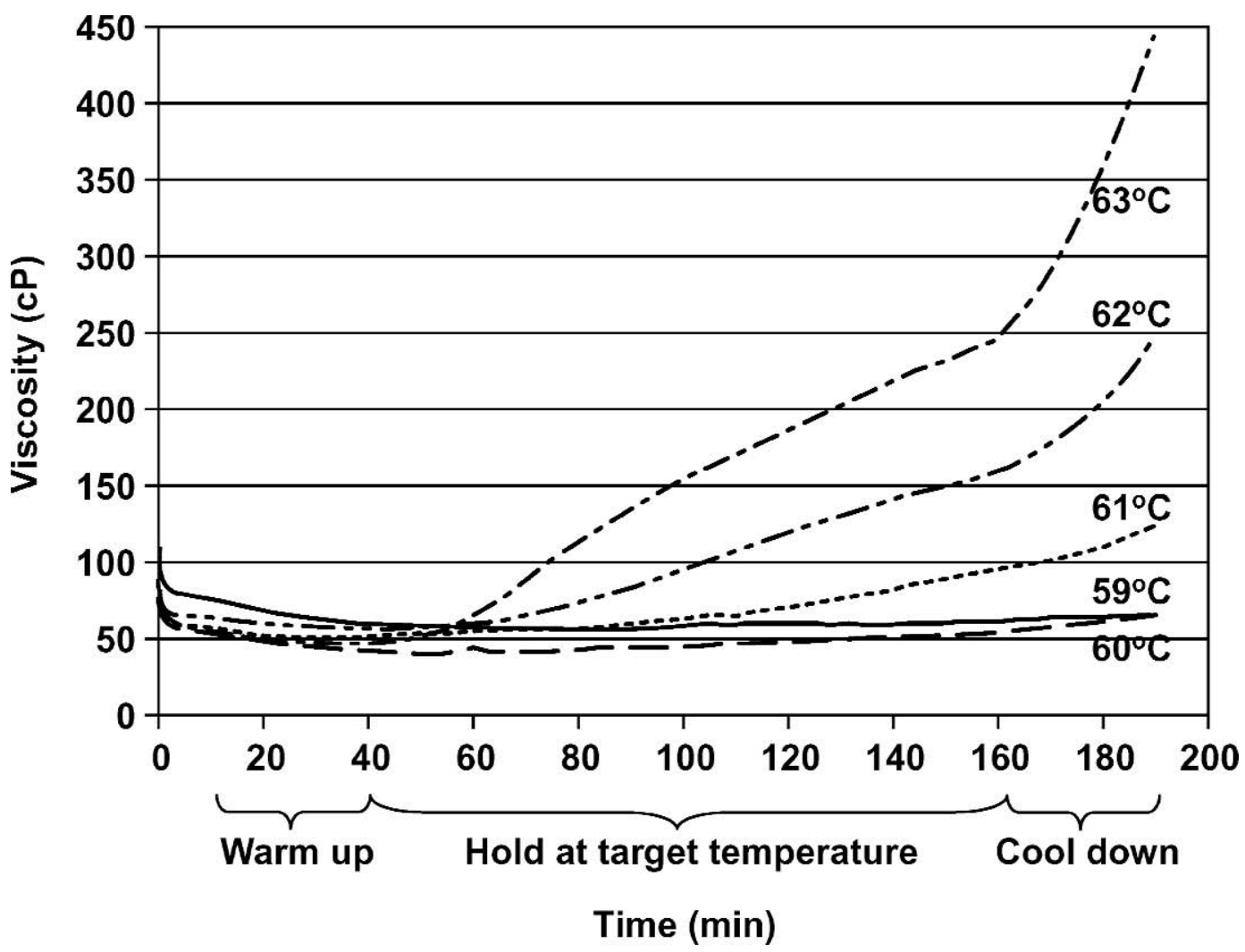

Figure 1. Viscosity changes during heat treatment of bovine colostrum at 5 temperatures for 120 min in a Rapid Visco Analyzer.

centration $(\mathrm{mg} / \mathrm{mL})$ in all pre- and post-heat-treated samples at each temperature, as well assess these variables for normality (skew, kurtosis). A linear regression model (PROC MIXED in SAS version 8.2, SAS Institute, 2000) was developed for each of the 5 temperatures studied, to describe the relationship between sample time (pre-heat-treatment vs. post-heat-treatment; explanatory variable) and the following 2 dependent variables of interest: 1) IgG concentration $(\mathrm{mg} /$ $\mathrm{mL}$ ), and 2 ) viscosity $\left[\log _{10}(\mathrm{cP})\right]$. Log-transformed data were used to describe viscosity measures because they are not normally distributed. Batch was controlled for as a random effect in the models.

For the additional work using 30 unique batches of colostrum heated to 2 different temperatures (60 and $63^{\circ} \mathrm{C}$ ), descriptive statistics were produced to describe measures for viscosity $\left[\log _{10}(\mathrm{cP})\right]$, IgG concentrations $(\mathrm{mg} / \mathrm{mL})$, and BVD SN titers in all pre-heat-treated and post-heat-treated samples, as well as the absolute changes and percentage changes in IgG and viscosity between pre- and post-heat-treated samples. A linear regression model (PROC MIXED in SAS version 8.2, SAS Institute, 2000) was developed for each of the 2 temperatures studied, to describe the relationship between sample time (pre- and post-heat-treated; ex- planatory variable) and the following 3 dependent variables of interest: 1$)$ IgG concentration $(\mathrm{mg} / \mathrm{mL}), 2)$ viscosity $\left[\log _{10}(\mathrm{cP})\right]$, and 3$)$ antibody activity $\left[\log _{2}(\mathrm{BVD}\right.$ SN titer)]. Log transformed data were used to describe viscosity measures and BVD SN titer because these measures are not normally distributed. Batch was controlled for as a random effect in the models.

Four more linear regression models were then developed to describe the relationship between temperature (60 or $63^{\circ} \mathrm{C}$; explanatory variable) and the following 4 dependent variables: 1 ) absolute change in IgG concentration $(\mathrm{mg} / \mathrm{mL})$ between pre- and post-heat-treated samples; 2) percentage change in IgG concentration (\%) between pre- and post-heat-treated samples; 3) absolute change in viscosity $\left[\log _{10}(\mathrm{cP})\right]$ between preand post-heat-treated samples; and 4) percentage change in viscosity (\%) between pre- and post-heattreated samples. A categorical term describing colostrum quality (high = pre-heat-treated IgG $\geq 73.0 \mathrm{mg}$ / $\mathrm{mL}$; moderate $=$ pre-heat-treated $\mathrm{IgG}<73.0 \mathrm{mg} / \mathrm{mL}$ ), as well as an interaction term between the variables describing temperature $\left(60\right.$ vs. $\left.63^{\circ} \mathrm{C}\right)$ and colostrum quality (high vs. moderate) were offered as covariates in these models. Because only 1 of the 30 batches of colostrum was considered to be of low quality $(<50 \mathrm{mg} /$ 
Table 1. Mean (SD; range) IgG concentration and viscosity for 6 batches of bovine colostrum after heat treatment at 5 different temperatures for 120 min in a Rapid Visco Analyzer

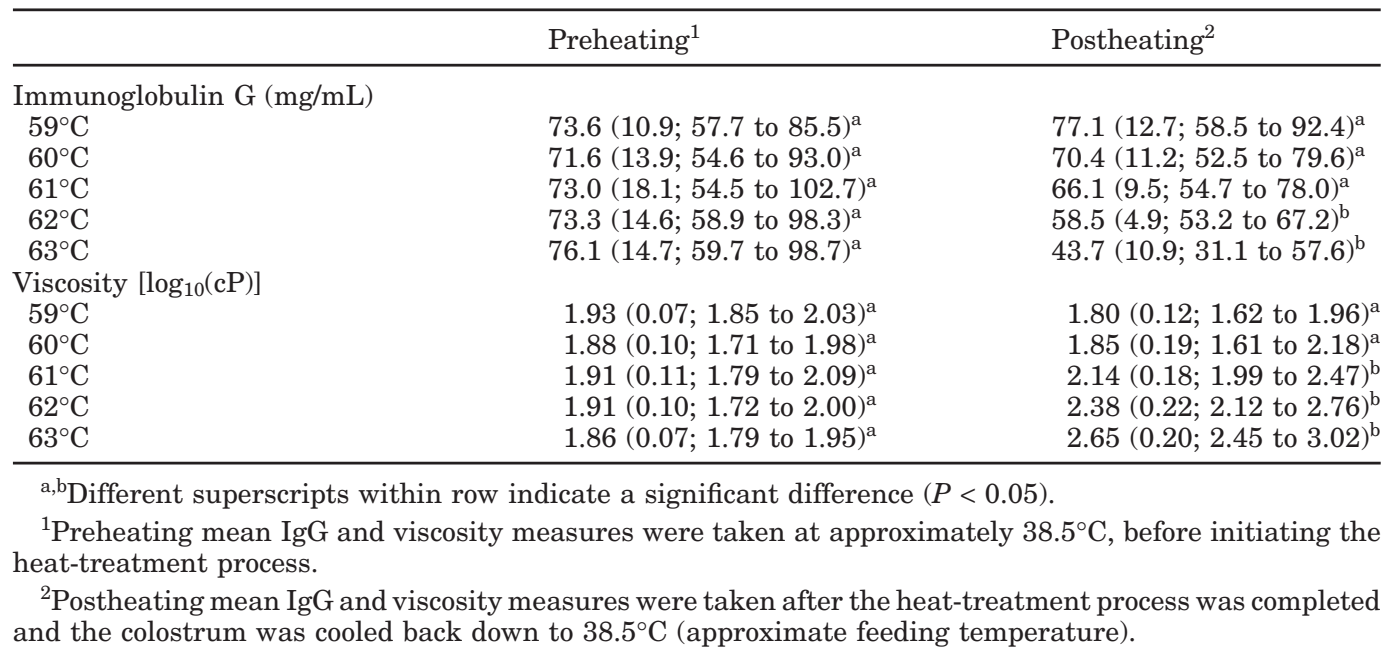

$\mathrm{mL}$ ), results from this batch were lumped into the "moderate" quality group. Batch was controlled for as a random effect in all models. Statistical significance was declared at $P<0.05$.

\section{RESULTS}

\section{Effect of Heat-Treatment Temperature on Viscosity and IgG Concentration}

For the preliminary work using 6 batches of colostrum heated at 5 different temperatures, regression analysis indicated that IgG concentration was reduced in post-heat-treated samples after colostrum was heated at 62 or $63^{\circ} \mathrm{C}$, and that viscosity was increased in post-heat-treated samples after colostrum was heated at 61,62 , or $63^{\circ} \mathrm{C}$ (Table 1 ). Viscosity measures, as recorded by the RVA every $8 \mathrm{~s}$ during the heating process at 59,60,61, 62, and $63^{\circ} \mathrm{C}$, are shown in Figure 1 . The results of this preliminary work strongly suggested that colostrum could be safely heated to $60^{\circ} \mathrm{C}$ without affecting either IgG concentration or viscosity. However, to confirm this, 30 unique batches underwent heating in the RVA at both 60 and $63^{\circ} \mathrm{C}$.

For the 30 unique batches of colostrum heated in the RVA at $60^{\circ} \mathrm{C}$, there were no differences in $\operatorname{IgG}$ concentration between pre-heat-treated samples (76.4 $\pm 26.5 \mathrm{mg} / \mathrm{mL})$ and post-heat-treated samples $(74.5 \pm$ $24.3 \mathrm{mg} / \mathrm{mL} ; P>0.05$; Table 2 and Figure 2). Similarly, there was no difference in viscosity $\left[\log _{10}(\mathrm{cP})\right]$ between pre-heat-treated samples $(1.90 \pm 0.26)$ and post-heattreated samples $(1.90 \pm 0.30 ; P>0.05$; Table 2$)$. However, for the 30 batches heated at $63^{\circ} \mathrm{C}$, there was a reduction in mean $\mathrm{IgG}$ concentration $(\mathrm{mg} / \mathrm{mL})$ in postheat-treated samples $(46.0 \pm 13.2)$ compared with pre- heat-treated samples $(77.0 \pm 26.1 ; P<0.05$; Table 2 and Figure 3). There was also an increase in mean viscosity $\left[\log _{10}(\mathrm{cP})\right]$ in post-heat-treated samples $(2.62$ $\pm 0.35)$ compared with pre-heat-treated samples (1.97 $\pm 0.21 ; P>0.05$; Table 2).

Further regression analysis indicated that heating colostrum to $63^{\circ} \mathrm{C}$ (vs. $60^{\circ} \mathrm{C}$ ) had an effect on the absolute loss $(\mathrm{mg} / \mathrm{mL})$ and the percentage loss of $\mathrm{IgG}$, and on the absolute change $\left[\log _{10}(\mathrm{cP})\right]$ and the percentage change in viscosity between pre- and post-heat-treated samples (Table 3, Figures 2 and 3). In the same 4 models, it was shown that high quality colostrum suffered from more pronounced losses in IgG and more pronounced increases in viscosity than did moderate quality colostrum (Figures 2 and 3). However, a significant interaction existed between temperature $(60$ vs. $63^{\circ} \mathrm{C}$ ) and colostrum quality (high vs. moderate) for models predicting absolute changes in IgG or absolute change in viscosity (but not for models predicting the percentage change in IgG or the percentage change in viscosity). As such, the data for the former 2 models were stratified by colostrum quality and reanalyzed (Table 3). For high quality colostrum $(\geq 73.0 \mathrm{mg} / \mathrm{mL})$, the least squares means estimate of the magnitude of IgG change was $-31.95(\mathrm{SE}=2.61)$ and $-4.62(\mathrm{SE}=$ $0.06) \mathrm{mg} / \mathrm{mL}$ for colostrum heated to 63 and $60^{\circ} \mathrm{C}$, respectively. Similarly, the least squares means estimate of the change in viscosity was $0.85(\mathrm{SE}=0.04)$ and $0.11(\mathrm{SE}=0.04) \log _{10}(\mathrm{cP})$ for high quality colostrum heated to 63 or $60^{\circ} \mathrm{C}$, respectively. By contrast, for moderate quality colostrum $(<73.0 \mathrm{mg} / \mathrm{mL})$ the magnitude of IgG change was estimated to be -18.11 (SE = $1.73)$ and $0.79(\mathrm{SE}=1.73) \mathrm{mg} / \mathrm{mL}$ for colostrum heated to 63 or $60^{\circ} \mathrm{C}$, respectively. Similarly, the estimated 
Table 2. Descriptive statistics (SD; range) for IgG concentration and viscosity for 30 batches of bovine colostrum after heat treatment at 2 temperatures for $120 \mathrm{~min}$ in a Rapid Visco Analyzer

\begin{tabular}{|c|c|c|c|c|}
\hline & Preheating & Postheating & Absolute change & Percentage change $(\%)$ \\
\hline \multicolumn{5}{|l|}{$\begin{array}{l}\text { Immunoglobulin } \mathrm{G} \\
(\mathrm{mg} / \mathrm{mL})\end{array}$} \\
\hline $60^{\circ} \mathrm{C}$ & $76.4(26.5 ; 42.6 \text { to } 155.5)^{\mathrm{a}}$ & $74.5(24.3 ; 44.3 \text { to } 147.3)^{\mathrm{a}}$ & $-1.9(7.4 ;-27.7$ to 13.8$)$ & $-1.6(7.1 ;-21.6$ to 10.3$)$ \\
\hline $63^{\circ} \mathrm{C}$ & $77.0(26.2 ; 40.9 \text { to } 159.8)^{\mathrm{a}}$ & $46.0(13.2 ; 21.0 \text { to } 87.8)^{\mathrm{b}}$ & $-24.3(11.1 ;-42.3$ to -4.3$)$ & $-33.9(13.3 ;-59.3$ to -8.6$)$ \\
\hline \multicolumn{5}{|l|}{ Viscosity $\left[\log _{10}(\mathrm{cP})\right]$} \\
\hline $\begin{array}{l}60^{\circ} \mathrm{C} \\
63^{\circ} \mathrm{C}\end{array}$ & $\begin{array}{l}1.90(0.26 ; 1.54 \text { to } 2.84)^{\mathrm{a}} \\
1.97(0.21 ; 1.66 \text { to } 2.81)^{\mathrm{a}}\end{array}$ & $\begin{array}{l}1.90(0.30 ; 1.41 \text { to } 2.82)^{\mathrm{a}} \\
2.62(0.35 ; 2.03 \text { to } 3.40)^{\mathrm{b}}\end{array}$ & $\begin{array}{c}-0.0024(0.20 ;-0.46 \text { to } 0.36) \\
0.65(0.28 ; 0.07 \text { to } 1.11)\end{array}$ & $\begin{array}{l}0.063(10.0 ;-20.72 \text { to } 16.54) \\
33.35(14.51 ; 3.6 \text { to } 58.2)\end{array}$ \\
\hline
\end{tabular}

${ }^{\mathrm{a}, \mathrm{b}}$ Different superscripts within row indicate significant difference between pre- and post-heat-treated measures $(P<0.05)$.

change in viscosity was estimated to be $0.45(\mathrm{SE}=0.05)$ and $-0.11(\mathrm{SE}=0.05) \log _{10}(\mathrm{cP})$ for moderate quality colostrum heated to 63 and $60^{\circ} \mathrm{C}$, respectively (Table $3)$.

\section{Effect of Heat-Treatment Temperature on Ig Activity}

Twenty-two and 21 paired samples of frozen colostrum, previously heated to 63 or $60^{\circ} \mathrm{C}$, respectively, were available for testing with a BVD SN assay to evaluate antibody activity. Unfortunately, this assay was able to produce results for only 18 of the postheat-treated samples heated at $60^{\circ} \mathrm{C}$ and for only 10 of the post-heat-treated samples heated at $63^{\circ} \mathrm{C}$. The explanation for this is that congealing of the colostrum in the assay precluded determination of a titer. As a result, only 18 and 10 paired pre- and post-heattreated SN test results were available for samples that had been heated at 63 or $60^{\circ} \mathrm{C}$, respectively. For the 18 paired colostrum samples heated to $60^{\circ} \mathrm{C}$ there was no decrease in titer when comparing the mean $( \pm \mathrm{SD}$; range) $\log _{2}$ (titer) for pre- $(12.4 \pm 1.8 ; 8.7$ to 15.0$)$ vs. post-heat-treated samples $(13.9 \pm 2.2 ; 11.0$ to 18.0$)$. Similarly, for the 10 paired colostrum samples heated to $63^{\circ} \mathrm{C}$, there was no decrease in titer when comparing the mean $\left( \pm \mathrm{SD}\right.$; range) $\log _{2}$ (titer) for pre- $(12.4 \pm 1.2$; 11.0 to 14.0$)$ vs. post-heat-treated samples $(12.3 \pm 1.6$; 10.0 to 15.0). These results should be interpreted with extreme caution given the large proportion of samples with missing results.

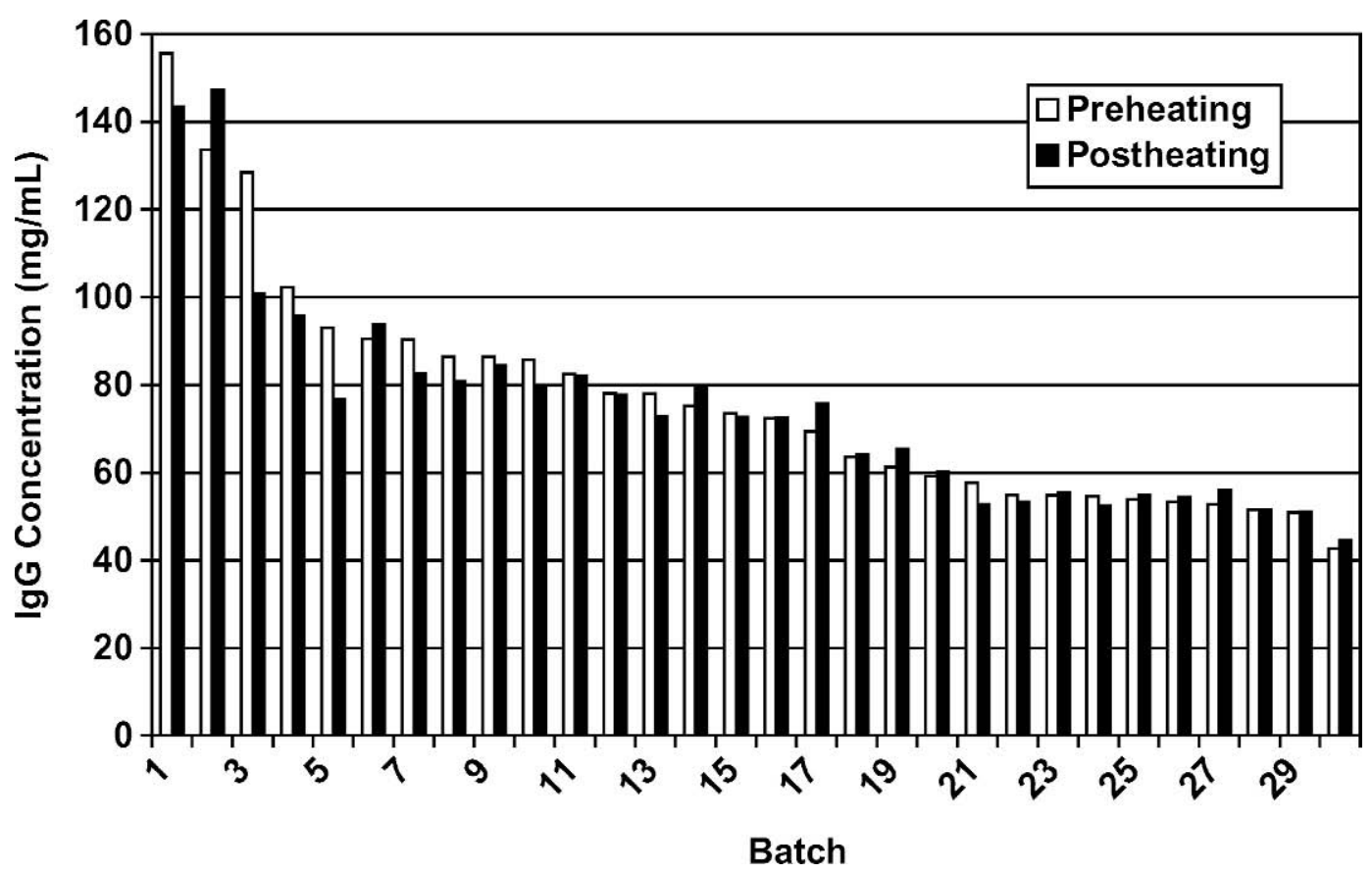

Figure 2. Immunoglobulin G concentrations in 30 pre- and post-heat-treated batches of colostrum when heating for 120 min at $60^{\circ} \mathrm{C}$ in a Rapid Visco Analyzer. 


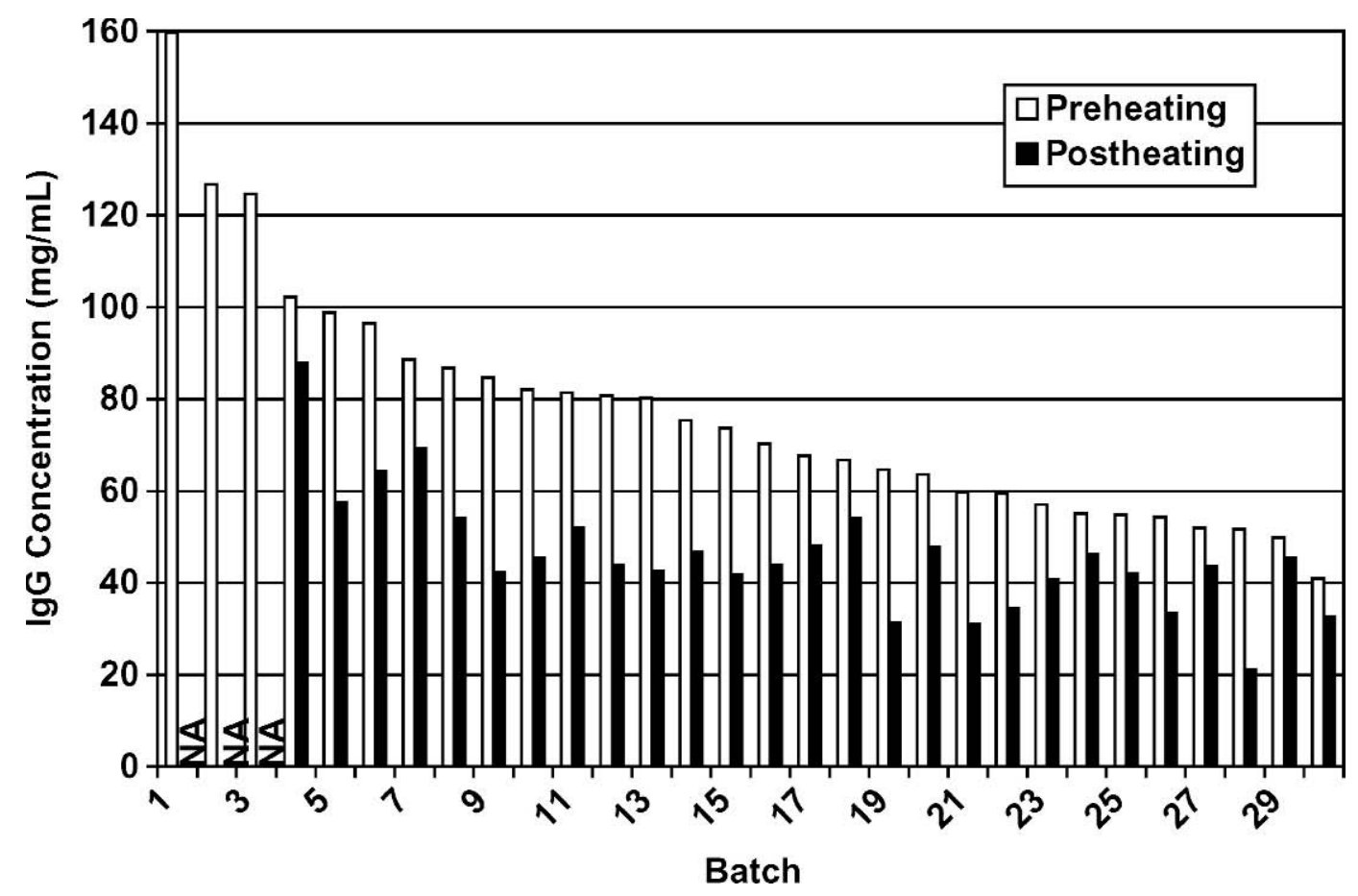

Figure 3. Immunoglobulin G concentrations in 30 pre- and post-heat-treated batches of colostrum when heating for 120 min at $63^{\circ} \mathrm{C}$ in a Rapid Visco Analyzer. NA = Results not available due to clumping of colostrum.

\section{DISCUSSION}

Pasteurization of bovine colostrum at the times and temperatures conventionally used for milk can successfully reduce or eliminate important bacterial pathogens including Salmonella spp., Listeria monocytogenes, E. coli O157 H7, Staphylococcus aureus (Green et al., 2002), and Mycobacterium avium ssp. paratuberculosis (Stabel et al., 2004). However, serious drawbacks to this practice include the denaturation of protective colostral antibodies and (sometimes) unacceptable increases in viscosity.

For example, in one experiment using an HTST approach, pasteurization of 5 unique 3.8-L batches of bovine colostrum at $72^{\circ} \mathrm{C}$ for $15 \mathrm{~s}$ using a large-scale, commercial, on-farm continuous flow pasteurizer (BetterMilk Inc., Winona, MN), resulted in an average $28.4 \%$ ( \pm 30.9 ) loss of IgG, with pre- and postpasteurized IgG concentrations being $58.5 \mathrm{mg} / \mathrm{mL}( \pm 10.7)$ and $41.3 \mathrm{mg} / \mathrm{mL}$ ( \pm 19.1 ), respectively (Green et al., 2003). Moreover, for all 5 batches, the colostrum congealed into a thick, pudding-like consistency during or immediately after the pasteurization process, creating a final product with unacceptable feeding and cleaning characteristics. In a separate experiment that heated colostrum at $71.7^{\circ} \mathrm{C}$ for $15 \mathrm{~s}$, using a commercial onfarm HTST pasteurization system, Stabel et al. (2004) reported a $25 \%$ reduction in $\operatorname{IgG}$ concentration and gelling of the finished product in the bucket.

Conventional batch pasteurization of colostrum is slightly more successful, but still has problems. Meylan et al. (1995) reported that batch pasteurization of 5 -mL aliquots from 18 colostrum samples at $63^{\circ} \mathrm{C}$ for 30 min resulted in a mean loss of only $12.3 \%( \pm 8.7)$ of IgG. However, given the small volumes studied, the external validity of these results is suspect. In a more recent laboratory study, pasteurization of 17 unique 3.8-L batches of bovine colostrum at $63^{\circ} \mathrm{C}$ for $30 \mathrm{~min}$, using a small-scale commercial batch pasteurizer (Weck Inc., Luray, VA), resulted in only mild thickening of the colostrum, but an average $25.3 \%( \pm 26.0)$ loss of IgG, with mean pre- and postpasteurized IgG concentrations being $68.7( \pm 17.8)$ and $48.9( \pm 15.2)$ $\mathrm{mg} / \mathrm{mL}$, respectively (Green et al., 2003). In a second experiment, pasteurization of 10 unique $30-\mathrm{L}$ batches of bovine colostrum at $63^{\circ} \mathrm{C}$ for $30 \mathrm{~min}$, using a largescale, commercial on-farm batch pasteurizer (DT-37, DairyTech Inc., Windsor, CO), resulted in only mild thickening, but an average 30.6\% ( \pm 19.3$)$ loss of IgG, with mean pre- and postpasteurized IgG concentrations being $59.7( \pm 13.5)$ and $40.0( \pm 10.0) \mathrm{mg} / \mathrm{mL}$, respectively (Green et al., 2003). Finally, in a controlled field study on a large commercial dairy in Colorado, an on-farm batch pasteurization system (DT-37, 
Table 3. Least squares means (SE) from final linear regression analysis of the effect of temperature on IgG and viscosity changes in 30 batches of colostrum heated at 2 temperatures for 120 min in a Rapid Visco Analyzer

\begin{tabular}{|c|c|c|c|}
\hline Dependent variable and model & \multicolumn{2}{|c|}{ Temperature } & $P$-value \\
\hline \multicolumn{4}{|l|}{ Absolute change in IgG concentration $(\mathrm{mg} / \mathrm{mL})$} \\
\hline Model 2: High quality colostrum $(\geq 73.0 \mathrm{mg} / \mathrm{mL})(\mathrm{n}=15)^{2}$ & $-31.95(2.61)$ & $-4.62(0.06)$ & $<0.0001$ \\
\hline Model 3: Moderate quality colostrum $(<73.0 \mathrm{mg} / \mathrm{mL})(\mathrm{n}=15)^{2}$ & $-18.11(1.73)$ & $0.79(1.73)$ & $<0.0001$ \\
\hline \multicolumn{4}{|l|}{ Absolute change in viscosity $\left[\log _{10}(\mathrm{cP})\right]$} \\
\hline Model 4: All batches of colostrum $(\mathrm{n}=30)^{1}$ & $0.65(0.04)$ & $-0.0019(0.04)$ & $<0.0001$ \\
\hline \multicolumn{4}{|l|}{ Percentage change in IgG concentration $(\%)$} \\
\hline Model 7: All batches of colostrum $(\mathrm{n}=30)^{1}$ & $-34.28(1.98)$ & $-1.23(1.88)$ & $<0.0001$ \\
\hline \multicolumn{4}{|l|}{ Percentage change in viscosity $(\%)$} \\
\hline Model 8: All batches of colostrum $(\mathrm{n}=30)^{1}$ & $33.30(2.03)$ & $0.07(2.06)$ & $<0.0001$ \\
\hline
\end{tabular}

${ }^{1}$ Models 1, 4, 7, and 8 control for initial colostrum quality (high vs. moderate) as a covariate in the model.

${ }^{2}$ Because a significant interaction between colostrum quality and temperature was detected in models 1 and 4 , models 2 , 3, 5 , and 6 were developed after stratifying the data by colostrum quality.

DairyTech, Inc.) was used to pasteurize 25 unique 57$\mathrm{L}$ (15-gallon) batches of fresh bovine colostrum to $63^{\circ} \mathrm{C}$ for 30 min (Godden et al., 2003). In this study, viscosity was only mildly increased. However, there was a mean loss of $23.6 \%$ ( \pm 12.9$)$ of IgG, with mean pre- and postpasteurized IgG concentrations being $58.7( \pm 12.5)$ and $44.1( \pm 9.2) \mathrm{mg} / \mathrm{mL}$, respectively. Furthermore, calves fed pasteurized colostrum had acceptable but numerically lower serum IgG concentrations $(13.5 \pm 2.2 \mathrm{mg} /$ $\mathrm{mL})$ than calves fed fresh colostrum $(16.1 \pm 2.4 \mathrm{mg} /$ mL; Godden et al., 2003).

The results of the current study agree with earlier studies (Godden et al., 2003; Green et al., 2003) in that heating bovine colostrum in a batch system to industry standard temperatures $\left(63^{\circ} \mathrm{C}\right)$ resulted in significant denaturation of IgG (least squares mean $=-34 \%$ reduction in IgG concentration) and a significant increase in viscosity (least squares mean $=+33 \%$ ). This experiment also detected that, when heated to $63^{\circ} \mathrm{C}$, high quality colostrum suffered from greater losses in IgG concentration and greater changes in viscosity than did moderate quality colostrum. This observation was also reported by Meylan et al. (1995) and Godden et al. (2003). Previous researchers (Lindstrom et al., 1994) utilized differential scanning calorimetry to determine that the denaturation temperature of $\mathrm{IgG}$ ranges from 62.6 to 67.6 , depending on the $\mathrm{pH}$. Consequently, when colostrum is heated above approximately $63^{\circ} \mathrm{C}$, thermally induced unfolding and subsequent aggregation of IgG can occur as a result of the exposure of hydrophobic or sulfur-containing amino acids. This explains both the increase in viscosity and the measurable decrease in IgG concentration that are reported in this and other studies when colostrum is heated to temperatures approaching or exceeding $63^{\circ} \mathrm{C}$.
Overall in this study, heating colostrum to $60^{\circ} \mathrm{C}$ resulted in no change in total IgG concentration (mg/ $\mathrm{mL}$ ) or viscosity when heating $50-\mathrm{mL}$ volumes in an RVA for up to $120 \mathrm{~min}$. Progressively greater reductions in IgG concentration and progressively greater increases in viscosity were observed for colostrum samples heated to 61,62 , and $63^{\circ} \mathrm{C}$, respectively. After stratifying the data by colostrum quality, there were no changes in IgG concentration or viscosity when heating moderate quality colostrum to $60^{\circ} \mathrm{C}$. However, when heating high quality colostrum to $60^{\circ} \mathrm{C}$, there were some minor losses in IgG $(-4.62 \mathrm{mg} / \mathrm{mL}$ or $-1.23 \%)$ and some minor increases in viscosity [0.11 $\log _{10}(\mathrm{cP})$ or $0.07 \%$ ]. Although of academic interest, these minor changes are not expected to be of practical importance because the end product should still be of very high quality with excellent feeding characteristics.

One of the objectives of this study was to evaluate the effect of temperature on antibody activity by use of a SN assay. Although the partial results reported would suggest that activity was not affected, readers should interpret these results with extreme caution given the dramatic loss of data (missing results) from this analysis attributed to congealing, particularly for the set of samples heated to $63^{\circ} \mathrm{C}$. Specifically, the SN assay results reported are likely to be highly biased because the omitted samples that congealed would most likely represent samples in which antibody activity would have been impaired. As such, the authors suggest that the partial SN results produced in this study should be interpreted as inconclusive.

The results of this research suggest that bovine colostrum can be successfully heated to $60^{\circ} \mathrm{C}$ for up to 120 min without affecting viscosity or reducing IgG 
concentration. However, there is a great deal more research to be completed before the practice of heattreating colostrum can be widely recommended for adoption by dairy producers. For example, the authors need to verify the external validity of this study's findings. That is, can the same results be achieved when heat-treating large volumes of colostrum in a commercial on-farm batch pasteurization system? Another obvious step would be to determine the duration of heating necessary, at this lower temperature, to kill important pathogens in colostrum such as E. coli, Salmonella spp., Listeria spp., Mycoplasma spp., and Mycobacterium avium ssp. paratuberculosis. Current industry standards recommend that batch pasteurization of milk be carried out at $63^{\circ} \mathrm{C}$ for $30 \mathrm{~min}$. It is expected that, by lowering the temperature to $60^{\circ} \mathrm{C}$ for colostrum, the duration of heating will need to be extended to achieve the same pathogen kill. The results of studies addressing these questions will be reported in a future companion paper.

Eventually, a controlled field study will be required to demonstrate that calf serum IgG concentrations, growth, and health are at least unaffected, if not improved, when calves are fed heat-treated colostrum. Ultimately, significant health, performance, and economic benefits must be described to justify feeding heat-treated colostrum to calves on commercial dairy farms.

\section{CONCLUSIONS}

Fifty-milliliter volumes of bovine colostrum can be heated at $60^{\circ} \mathrm{C}$ in an RVA for at least 120 min without affecting IgG concentration or viscosity. Additional research is needed to determine if these study findings can be successfully replicated when using a large-scale commercial on-farm batch pasteurization system, and to determine the duration of heating required at $60^{\circ} \mathrm{C}$ to effectively destroy important pathogens in colostrum.

\section{ACKNOWLEDGMENTS}

We would like to thank the staff and management at the Transition Management Facility (Emerald Dairy II, Emerald, WI) for providing bovine colostrum for this study. Funding for this study was provided by USDA:APHIS (Veterinary Services Division) and by the Merck-Merial Summer Scholars Program.

\section{REFERENCES}

Clark, R. C., S. A. McEwen, V. P. Gannon, H. Lior, and C. L. Gyles. 1989. Isolation of verocytotoxin-producing Escherichia coli from milk filters in Southwestern Ontario. Epidemiol. Infect. 102:253-260.
Davis, C. L., and J. K. Drackley. 1998. The Development, Nutrition, and Management of the Young Calf. 1st ed. Iowa State University, Ames.

Etzel, L. R., R. E. Strohbehn, and J. K. McVicker. 1997. Development of an automated turbidometric immunoassay for quantification of bovine serum immunoglobulin G. Am. J. Vet. Res. 48:12011205.

Farber, J. M., G. W. Sanders, and S. A. Malcolm. 1988. The presence of Listeria spp. in raw milk in Ontario. Can. J. Microbiol. 34:95-100.

Giles, N., S. A. Hopper, and C. Wray. 1989. Persistence of S. typhimurium in a large dairy herd. Epidemiol. Infect. 103:235-241.

Godden, S. M., J. P. Fetrow, J. M. Feirtag, L. R. Green, and S. J. Wells. 2005. Economic analysis of feeding pasteurized nonsaleable milk versus conventional milk replacer to dairy calves. J. Am. Vet. Med. Assoc. 226:1547-1554.

Godden, S. M., S. Smith, J. M. Feirtag, L. R. Green, S. J. Wells, and J. P. Fetrow. 2003. Effect of on-farm commercial batch pasteurization of colostrum on colostrum and serum immunoglobulin concentrations in dairy calves. J. Dairy Sci. 86:1503-1512.

Green, L., S. Godden, and J. Feirtag. 2002. Pasteurization effects on Mycobacterium paratuberculosis, E. coli O157:H7, Salmonella sp., Listeria monocytogenes, and Staphylococcus aureus. Page 190 in Proc. Am. Assoc. Bovine Pract. 35th Annu. Conv., Madison, WI. Am. Assoc. Bovine Pract., Stillwater, OK.

Green, L., S. Godden, and J. Feirtag. 2003. Effect of batch and high temperature-short time pasteurization on immunoglobulin G concentrations in colostrum. J. Dairy Sci. 86(Suppl. 1):246. (Abstr.)

Jamaluddin, A. A., T. E. Carpenter, D. W. Hird, and M. C. Thurmond. 1996. Economics of feeding pasteurized colostrum and pasteurized waste milk to dairy calves. J. Am. Vet. Med. Assoc. 209:751-756

Lindstrom, P., M. Paulsson, T. Nylander, U. Elofsson, and H. Lindmark-Mansson. 1994. The effect of heat treatment on bovine immunoglobulins. Milchwissenschaft 49:67-71.

Lovett, J., D. W. Francis, and J. M. Hunt. 1983. Isolation of Campylobacter jejuni from raw milk. Appl. Environ. Microbiol. 46:459462.

McEwen, S. A., W. Martin, R. C. Clarke, and S. E. Tamblyn. 1988. A prevalence survey of Salmonella in raw milk in Ontario, 198687. J. Food Prot. 51:963-965.

McGuirk, S., and M. Collins. 2004. Managing the production, storage and delivery of colostrum. Pages 593-603 in Vet. Clin. North Am. Food Anim. Pract. Managing the Transition Cow to Optimize Health and Productivity. W. B. Saunders Co., New York, NY.

McVicker, J. K., G. C. Rouse, M. A. Fowler, B. H. Perry, B. L. Miller, and T. E. Johnson. 2002. Evaluation of a lateral-flow immunoassay for use in monitoring passive transfer of immunoglobulins in calves. Am. J. Vet. Res. 63:247-250.

Meylan, M., M. Rings, W. P. Shulaw, J. J. Kowalski, S. Bech-Nielsen, and G. F. Hoffsis. 1995. Survival of Mycobacterium paratuberculosis and preservation of immunoglobulin $\mathrm{G}$ in bovine colostrum under experimental conditions simulation pasteurization. Am. J. Vet. Res. 57:1580-1585.

National Animal Health Monitoring System (NAHMS). 1993. Dairy Heifer Morbidity, Mortality and Health Management Practices Focusing on Preweaned Heifers. Pages 5-10 in National Dairy Heifer Evaluation Project. USDA:APHIS Veterinary Services, Ft. Collins, CO.

National Animal Health Monitoring System (NAHMS). 1996. NAHMS Dairy 1996: Part II: Changes in the U.S. Dairy Industry: 1991-1996; pages 17-20. USDA-APHIS Veterinary Services, Ft. Collins, CO.

National Animal Health Monitoring System. 2002. Dairy 2002. Part 1: Reference of Dairy Health and Management in the United States; pages 57-58 in USDA:APHIS Veterinary Services, Ft. Collins, CO.

Poulsen, K. P., F. A. Hartmann, and S. M. McGuirk. 2002. Bacteria in colostrum: Impact on calf health. Page 773 (Abstr. 52) in Proc. 20th Am. Coll. Intern. Vet. Med., Dallas, TX. Am. Coll. Intern. Vet. Med., Lakewood, CO. 
SAS Institute. 2000. SAS User's Guide. Statistics. Release 8.2. SAS Institute Inc., Cary, NC.

Stabel, J. R., S. Hurd, L. Calvente, and R. F. Rosenbusch. 2004. Destruction of Mycobacterium paratuberculosis, Salmonella spp., and Mycoplasma spp. in raw milk by a commercial onfarm high-temperature, short-time pasteurizer. J. Dairy Sci. 87:2177-2183.

Steele, M. L., W. B. McNab, C. Poppe, M. W. Griffiths, S. Chen, S. A. Degrandis, L. C. Fruhner, C. A. Larkin, J. A. Lynch, and J. A. Odumeru. 1997. Survey of Ontario bulk tank raw milk for food-borne pathogens. J. Food Prot. 60:1341-1346.

Stewart, S., S. Godden, R. Bey, P. Rapnicki, J. Fetrow, R. Farnsworth, M. Scanlon, Y. Arnold, L. Clow, K. Mueller, and C. Ferrou- illet. 2005. Preventing bacterial contamination and proliferation during the harvest, storage and feeding of fresh bovine colostrum. J. Dairy Sci. 88:2571-2578.

Streeter, R. N., G. F. Hoffsis, S. Bech-Nielsen, W. P. Shulaw, and D. M. Rings. 1995. Isolation of Mycobacterium paratuberculosis from colostrum and milk of subclinically infected cows. Am. J. Vet. Res. 56:1322-1324.

Walz, P. H., T. P. Mullaney, J. A. Render, R. D. Walker, T. Mosser, and J. C. Baker. 1997. Otitis media in preweaned Holstein dairy calves in Michigan due to Mycoplasma bovis. J. Vet. Diagn. Invest. 9:250-254.

Wells, S. J., D. A. Dargatz, and S. L. Ott. 1996. Factors associated with mortality to 21 days of life in dairy heifers in the United States. Prev. Vet. Med. 29:9-19. 